Tokyo, Japan

priyanka.borpujari@gmail.com Cite this as: BMJ 2021;374:n2102 http://dx.doi.org/10.1136/bmj.n2102 Published: 27 August 2021

\section{How the pandemic Olympics affected Japan}

\author{
The delayed Tokyo Olympics arrived just as Japan faced its biggest surge of covid-19 so far. Priyanka \\ Borpujari asks how the city, and the country, coped and whether worries over the event played out
} Priyanka Borpujari freelance journalist

The sound of sirens across Tokyo has increased noticeably during August. After a year of keeping the pandemic in check, Japan's health system faces its sternest test yet, with record breaking numbers of daily cases.

At the start of the year, the capital had around 800 new cases a day. ${ }^{1}$ By mid-August it was seeing over 5000 after a steep climb since mid-July. Tokyo has around 6000 beds for covid-19 patients, ${ }^{2}$ and as of 25 August, 4154 of these were occupied, with 277 people having severe symptoms. Numerous reports show many people having to wait for hours after calling an ambulance. On 19 August a newborn died after the mother, who had covid-19, was unable to find a hospital that would admit her, and she was forced to give birth at home. ${ }^{3}$ Although daily deaths remain relatively low compared with other countries, the current count of around 40 a day is double that of mid-July.

The latest rise in cases jostled for headlines with the city's much anticipated hosting of the Olympic Games, delayed by a year, and conducted as the new wave was growing. The decision to continue with the event-which brought over 18 ooo foreign athletes, delegates, and other officials to Tokyo-despite the surge was much debated. Public reaction was mixed. In June, a national survey found that $86 \%$ of people in Japan were worried that the Olympics would lead to a rebound of covid-19 cases in Tokyo. ${ }^{4}$ As cases continued to rise, calls for the Games to be cancelled became louder. An online petition was signed by 450 ooo people ${ }^{5}$ as Tokyo reported over 1300 new infections a week before the Games-only the second time it had breached the 1000 mark since August $2020 .^{6}$

The president of the International Olympic Committee (IOC), Thomas Bach, maintained that there was "zero" risk of the athletes infecting Japanese residents. ${ }^{7}$ An Olympics village bubble was planned to protect the athletes and everyone associated with the Games, as well as prevent any spread of infection. Under an agreement with Pfizer and the IOC, Japan secured enough doses for around 40 ooo workers related to the Games: staff, media, and volunteers.

Yet until early May, only about 3\% of the Japanese population was fully vaccinated, with 250 ooo shots administered daily. It was not until 25 June-about a month before the Olympics-that the country was administering a million doses a day. ${ }^{8}$ Around $8.2 \%$ of the adult population was vaccinated by then, and workplace vaccinations also began around the same time-the government received nearly 4000 applications, not only from companies but also from universities. By the end of the Games on 9 August,
$30 \%$ of Japan's population had received their first dose of the vaccination and only $18 \%$ had been completely vaccinated.

\section{Let the Games begin}

In the end, there were no spectators across the 43 venues, as a state of emergency-Tokyo's fourth, which began on 12 July-was extended to the end of August (it has since been widened to apply to 21 of Japan's 47 prefectures). Among the restrictions in place, dining establishments were not permitted to serve alcohol and were expected to shut by $8 \mathrm{pm}$, with businesses fearing the economic effects during what should have been a bumper period for custom.

On the day of the opening ceremony of the Games, Japan recorded 4200 new infections. By the closing ceremony that figure had tripled to 12073.

A total of 151 people affiliated to the Olympics tested positive during the two weeks of the Games; they were immediately isolated and sent for treatment. Some high profile protocol breaks occurred: two judo athletes from Georgia were ejected from the event and stripped of accreditation after going sightseeing. ${ }^{9}$ Olympic athletes and affiliated officials were told to adhere to the "playbook," which suggested restricted activities for the first 14 days after entering Japan.

More recently, it emerged that one woman associated with the Olympics was infected with the lambda strain of covid-19 when she entered Japan in July, ${ }^{10}$ the first known case in the country according to one government official. ${ }^{10}$

Japan's minister for the Olympics and Paralympics, Tamayo Marukawa, maintains that the Olympics hasn't affected covid-19. "I don't think the Olympics caused infections to spread," ${ }^{11}$ he said at a press conference.

But Kenji Shibuya, director of the covid vaccination medical centre in Soma city, said that although the Games had no direct effect on local transmission, it brought about a sentiment of celebration and excitement. "It is summertime, and people are tired of repeated states of emergency. And then the Olympics came in, and obviously there was a flow of movement," said Shibuya.

"Within the Olympics village, people were tested almost daily and almost everyone was vaccinated. Outside the bubble, the situation was completely the opposite. So there is a clear double standard here," Shibuya added.

Still, the public's attitude softened somewhat as the Games began. Later surveys found the proportion wanting cancellation dwindling, and most supported 
the event going ahead in some form as a sense of inevitability set in. A survey after the Games ended showed $64 \%$ were glad it had taken place. ${ }^{12}$

Public patience was tested, however. Shortly after the Games ended, Bach was seen out walking through the city, ${ }^{13}$ causing a stir on social media since Tokyo residents had been asked to refrain from non-essential outings. One minister defended Bach's actions by explaining that he had arrived in Japan on 8 July and had therefore passed the 14 day quarantine restriction. Athletes and other Olympic related workers were also spotted touring Tokyo's popular Akihabara district after the Games ended. ${ }^{14}$

\section{The Games continue}

Japan's pandemic situation remains perilous. New infections are currently over 25000 a day nationally, and the state of emergency will last until at least 12 September. ${ }^{15}$ As the Paralympics began on 24 August, Tokyo broke its record for consecutive daily new infections (over 5400). ${ }^{16}$

"It is surprising that nobody was talking about whether the Paralympics would be cancelled," says Shibuya, "Nobody wanted to touch upon it, and that is very irresponsible."

Masataka Inokuchi, a vice chair of the Tokyo Medical Association, has declared the capital's circumstance as "a disaster level emergency situation that is out of control," worrying about the medical system and paramedic response. ${ }^{17}$ Tokyo's metropolitan government has been trying to increase hospital capacity and had also prepared 6240 rooms across 16 empty hotels as temporary facilities for patients with mild or asymptomatic infection who need to isolate but don't require hospital treatment. ${ }^{18}$ But then came another hurdle: a staff shortage meaning that only 1800 of those rooms could be used. As of 12 August, 1762 rooms were already occupied.

Additionally, around 60000 people are already isolating in their homes across Tokyo and its neighbouring prefectures of Kanagawa, Chiba, and Saitama. Doctors have been forced to tell covid-19 patients-most of them in their 20 and 30s, and infected with the delta variant-to wait at home for an available hospital bed and that deteriorating health would still not guarantee a bed. ${ }^{19}$

Ambulances take hours to arrive, and Tokyo's Fire and Disaster Management Agency says it struggled to find medical facilities willing to take in the 2897 callers they dealt with in just the first week of August. ${ }^{18}$ Of those, $48 \%$ were possibly infected with covid-19, according to the agency. It was the first time since the pandemic that calls had gone beyond 1000, it said.

The worsening situation forced Tokyo's governor, Yuriko Koike, to shift her position from asking people to consider changing their travel plans during the traditional Obon holidays, to giving up their plans entirely. ${ }^{20}$ This drew ire from the public, since her office did not heed the appeals to cancel the Olympics. One survey reported that $61 \%$ of respondents believed the Olympics had lowered the temperament of caution against the virus. ${ }^{21}$

The federal government continues rushing to get more people vaccinated. By 24 August, Japan had administered nearly 120 million vaccine doses, and government statistics show $86.2 \%$ of over $65 \mathrm{~S}$ are fully vaccinated, with $89 \%$ having had at least one dose. ${ }^{22}$ But figures from 10 August showed that only $12 \%$ of adults younger than 65 were fully vaccinated,,$^{23}$ the lowest vaccination rate among the $\mathrm{G} 7$ nations.

As the Paralympics goes ahead, again with no spectators, so far three athletes have tested positive and been sent for self-isolation. ${ }^{24}$
And the question of how much the Games may entwine with the new wave shows no sign of disappearing.

Competing interests: I have read and understood BMJ policy on declaration of interests and have no relevant interests to declare.

Provenance and peer review: Commissioned; not externally peer reviewed.

Coronavirus (covid-19) cases. Tokyo.

https://www.google.com/url?q=https://news.google.com/covid19/map?hl\%3Den-

US\%26mid\%3D\%252Fm\%252F07dfk\%26gl\%3DUS\%26ceid\%3DUS\%253Aen\&sa=D\&source=editors\&ust=1629798105871000\&usg=AOvVaw1p3fEID9IZ9FIffWOmE1UI

Updates on covid-19 in Tokyo, 24 Aug 2021. https://stopcovid19.metro.tokyo.lg.jp/en

COVID-19 patient forced to give birth at home, baby dies. Asahi Shimbum 2021 Aug 19.

https://www.asahi.com/aiw/articles/14421133

86\% in Japan fear COVID-19 rebound if Tokyo Olympics held, poll shows. Japan Times 2021 Jun 20. https://www.japantimes.co.jp/news/2021/06/20/national/olympic-poll-coronavirus/

5 IOC aware of Japan scepticism over Games, hopes home success will shift mood. Reuters 2021 Jul 17. https://www.reuters.com/lifestyle/sports/ioc-aware-japanese-scepticism-games-hopessuccess-will-shift-attitudes-2021-07-17/

6 Over 1,200 more coronavirus cases reported in Japan at holiday peak. Kyodo News 2020 Aug 15. https://english.kyodonews.net/news/2020/08/48a7f08121e2-tokyo-reports-385-morecoronavirus-cases-more-than-380-for-2nd-day.html

Risk of COVID spread is 'zero', IOC chief says, amid rising cases.

https://www.reuters.com/world/asia-pacific/olympics-ioc-chief-tokyo-governor-meet-covid-casesrise-2021-07-15/

8 Is Japan's remarkable vaccine drive in time for Olympics? Associated Press, 25 Jun 2021. https://apnews.com/article/japan-coronavirus-vaccine-coronavirus-pandemic-olympic-gamesbusiness-e96163aadba182bf39c26a4c12fa68b4

9 Two Georgian judoka ordered to leave Olympics for breaking Covid rules. Guardian 2021 Aug 1. https://www.theguardian.com/sport/2021/aug/01/two-georgian-judoka-ordered-to-leave-olympics for-breaking-covid-rules

10 The first confirmation of Lambda strain infection in Japan is related to the Olympics. https://nordot.app/798814984534065152?c=

11 Olympic minister says Games didn’t cause Japan’s COVID infection surge. Mainichi2021 Aug 10 https://mainichi.jp/english/articles/20210810/p2a/00m/0na/027000c

12 New Olympics poll from Yomiuri is even clearer. Twitter, 10 Aug 2021. https://twitter.com/GearoidReidy/status/1424880565380030483

13 Social media abuzz over IOC chief's post-Olympic stroll. Japan Times 2021 Aug 10 https://www.japantimes.co.jp/news/2021/08/10/national/bach-tokyo-walkabout/

14 Athletes' Tokyo excursions in final Olympic days suggest 'bubble' has popped. Mainichi2021 Aug 11. https://mainichi.jp/english/articles/20210811/p2a/00m/0na/021000c

15 Japan's infection cases hit record for third day. NHK, 20 Aug 2021. https://www3.nhk.or.jp/nhkworld/en/news/20210820_22/

165405 new coronavirus cases recorded in Tokyo on Aug 20. Mainichi 2021 Aug 20. https://mainichi.jp/english/articles/20210820/p2a/00m/0na/001000c

17 Disease experts seek halving of Tokyo foot traffic to curb COVID. Nikkei2021 Aug 12.https://asia.nikkei.com/Spotlight/Coronavirus/Disease-experts-seek-halving-of-Tokyo-foottraffic-to-curb-COVID

18 Tokyo area COVID-19 outbreak exacerbated by medical staff shortages. Japan Times 2021 Aug 13. https:/www.japantimes.co.jp/news/2021/08/13/national/tokyo-outbreak-staff-shortage/

19 Tokyo doctors fear surge in deaths of virus patients at home. Asahi Shimbun 2021 Aug 12 https://www.asahi.com/ajw/articles/14416320

20 Governor Koike "Give up on homecoming" and the citizens of Tokyo are out! "Did you give up your opinion and listen to the Olympics?” Yahoo Japan, 13 Aug 2021. https://news.yahoo.co.jp/ar ticles/a79862e582af47484d88b6edf9dae3cd302b83d9

21 Self-restraint mood at the Olympics "Loose" 61\% Asahi Shimbun opinion poll. Asahi Shimbun 2021 Aug 8. https://www.asahi.com/articles/ASP886DCNP86UZPS003.html

22 Japan vaccinations rise to 119.8 million. Twitter 24 Aug 2021. https://twitter.com/GearoidReidy/status/1430102627484782593

23 Half of Japan's population has received at least one dose of a covid-19 vaccine. Japan Times 2021 Aug 18. https://www.japantimes.co.jp/news/2021/08/18/national/japan-covid-vaccine-status/

24 Two more Paralympic athletes test positive for covid-19 in Tokyo village. Guardian2021 Aug 25. https://www.theguardian.com/sport/2021/aug/25/two-more-paralympic-athletes-test-positivefor-covid-19-in-tokyo-village

This article is made freely available for use in accordance with BMJ's website terms and conditions for the duration of the covid-19 pandemic or until otherwise determined by BMJ. You may use, download and print the article for any lawful, non-commercial purpose (including text and data mining) provided that all copyright notices and trade marks are retained. 